\title{
RESPONSABILIDADE DO ADVOGADO NOS CASOS DE PLANEJAMENTO TRIBUTÁRIO
}

\author{
LAWYER'S RESPONSIBILITY IN CASES OF TAX PLANNING
}

\author{
Fernando Gustavo Knoerr ${ }^{1}$ \\ Fabiana Caricati ${ }^{2}$
}

\begin{abstract}
Resumo
O presente trabalho faz uma análise sobre a responsabilidade do advogado, inicialmente a responsabilidade civil, caracterizada como sendo subjetiva, contratual e sua obrigação de meio. Em seguida, foi possível analisar a responsabilidade précontratual, contratual e pós-contratual do advogado, consoante a normativa civil e o Código de Ética e Disciplina da Ordem dos Advogados do Brasil, identificando o que se espera do profissional, no exercício desta atividade indispensável à Justiça, ao Direito e a sociedade. Caminhando para o fim, este trabalho buscou verificar a responsabilidade do advogado nos casos de estruturação de planejamento tributário, considerando os entendimentos adotados pelos órgãos julgadores na esfera administrativa e judicial. Para a elaboração deste estudo, a metodologia utilizada foi a pesquisa bibliográfica, bem como a pesquisa dos entendimentos dos órgãos administrativos e judiciais a respeito da matéria.
\end{abstract}

Palavras-chave: advogado, contrato, ética, responsabilidade, dano.

\begin{abstract}
The present work makes an analysis on the liability of the lawyer, initially the civil liability, characterized as being subjective, contractual and its obligation of means. Then, it was possible to analyze the pre-contractual, contractual and post-contractual liability of the lawyer, according to the civil rules and the Code of Ethics and Discipline of the Brazilian Bar Association, identifying what is expected of the professional, in the exercise of this activity indispensable to justice, law and society. Moving towards the end, this work sought to verify the responsibility of the lawyer in cases of structuring

\footnotetext{
1 Doutor em Direito do Estado pela Universidade Federal do Paraná (2002). Mestre em Direito do Estado pela Universidade Federal do Paraná (1998). Bacharel em Direito pela Universidade Federal do Paraná (1993). Ex-Procurador Federal. Professor de Direito Administrativo da Escola da Magistratura do Paraná e da Fundação Escola do Ministério Público do Paraná / FEMPAR. É Professor Permanente do Programa de Mestrado em Direito Empresarial e Cidadania do UNICURITIBA. Realizou estágio PósDoutoral na Universidade de Coimbra, Portugal

${ }^{2}$ Advogada. Fundadora do escritório Caricati Advocacia. Doutoranda do Programa de Pós-Graduação Strictu Sensu em Direito Empresarial e Cidadania no Centro Universitário Curitiba - Unicuritiba, Paraná. Especialista em Direito Tributário pela Universidade Estadual de Maringá, PR e em Contabilidade e Auditoria de Tributos pela FAE Business School, em Curitiba, Paraná. Presidente da Comissão de Direito Tributário da Associaçao Brasileira de Advogados. Membro da Comissão de Direito Tributário da OABPR e do Instituto de Direito Tributário do Paraná. Email: fabiana@caricati.adv.br
} 
tax planning, considering the understandings adopted by the judging bodies in the administrative and judicial spheres. For the elaboration of this study, the methodology used was the bibliographic research, as well as the research of the understandings of the administrative and judicial organs regarding the matter.

Keywords: lawyer, contract, ethics, responsibility, harm.

\section{INTRODUÇÃO}

A categoria profissional dos advogados está sendo detentora de baixo índice de respeito e credibilidade, devido ao comportamento de alguns profissionais que na tentativa de obter pra si grandes lucros, acabam se envolvendo em práticas antiéticas, ilícitas ou desonrosas para toda a categoria.

Diante desta problemática, é que foi aceita a tarefa de escrever sobre ética e a responsabilidade do advogado, ainda que poucos foram os corajosos doutrinadores que abordaram o tema com amplitude, ponderando sobre as peculiaridades da responsabilidade do profissional do Direito e das condutas que podem gerar o dever de indenizar.

Foram utilizados os métodos dedutivos e descritos e a revisão bibliográfica obras jurídicas, artigos científicos e textos legais, para então, partindo de uma análise geral sobre a responsabilidade civil do advogado e seu enquadramento na espécie de responsabilidade subjetiva, contratual e sua obrigação de meio que emerge da celebração do contrato, pela vontade das partes contratantes, foi direcionado o estudo para as hipóteses de responsabilidade pré-contratual, contratual e póscontratual do causídico, enfocando a sua condição de elemento indispensável à Administração daJustiça.

Por fim, objetivando analisar a responsabilidade civil ou criminal dos advogados nos casos de estruturação do planejamento tributário, partiu-se da análise do instituto do próprio planejamento fiscal, como forma ilícita de gestão de tributos, identificando precedentes administrativos e judiciais que buscam responsabilizar o advogado em casos em que o planejamento fiscal promove a evasão fiscal, como também o sentido oposto dos precedentes que afastam a sua responsabilização, respaldando-se no texto constitucional que prescreve que o advogado, sendo indispensável à administração da justiça, é inviolável por seus atos e manifestações no exercício da advocacia. 
No exercício de atividade privada, mas por prestar serviço público de grande relevância para assegurar os direitos e garantias individuais dos cidadãos e dos grupos sociais, objetivou-se fazer este trabalho como forma de contribuição para toda a classe, direcionando- a nas práticas éticas e dentro dos parâmetros legais, como forma de reconquistar a credibilidade de toda a categoria.

\section{DA RESPONSABILIDADE CIVIL}

A responsabilidade civil, já em 2003, dizia Maria Helena Diniz, ser um dos temas mais problemáticos da atualidade jurídica (DINIZ, 2003, p.03), ante sua expansão no Direito Moderno e seus reflexos nas diversas atividades humanas e no avanço tecnológico que impulsiona o progresso material.

O tema é um fenômeno de todos os domínios da vida social (STOCO, 2001, p.90) erepercute nas mais diversas manifestações de atividades que provocam um prejuízo, pois cada atentado sofrido pelo homem relativo à sua pessoa ou ao seu patrimônio constitui um desequilíbrio de ordem moral ou patrimonial, tornando imprescindível a criação de soluções que sanem tais lesões, já que o Direito não pode tolerar que ofensas fiquem sem reparação.

A importância da responsabilidade civil está na restauração do equilíbrio moral ou patrimonial desfeito e a redistribuição da riqueza, conforme os ditames da justiça, tutelando a pertinência de um bem a um sujeito determinado.

O jurista Silvio Rodrigues (RODRIGUES, 2002, p.06) define a responsabilidade civil comosendo:

\footnotetext{
A obrigação que pode incumbir uma pessoa a reparar o prejuízo causado a outra, por fato próprio ou por fato de pessoa ou coisas que dela dependam.
}

Partindo deste conceito, a doutrina definiu espécies de responsabilidade civil, dentre elas, as que serão abordadas neste trabalho é a subjetiva, a objetiva, a contratual e a extracontratual, tendo o objetivo do enquadramento da responsabilidade civil do advogado no ordenamento jurídico.

Por responsabilidade subjetiva, adotado pela quase unanimidade dos 
códigos do passado, a responsabilidade estava fundada sobre o conceito de culpa (VENOSA, 2003, p.6), o que equivale dizer que somente se provada a culpa do agente é que emergia a necessidade de reparar odano.

Essa noção clássica de culpa sofreu grande atenuação por serconsideradainsuficiente para atender aos problemas que a vida atual apresenta. O desenvolvimento da ciência e da tecnologia, o progresso do maquinismo, a mecanização dos meios de transportes, dentre outros, trouxeram um aumento brutal de acidentes, com crescente número de vítimas,visualizando então a necessidade de proporcionar a elas os meios adequados de ressarcimento.

Diante disso, a teoria da culpa foi sendo mitigada por outra construção jurídica, a teoria da responsabilidade objetiva, fundada no risco.

A responsabilidade objetiva desconsidera a culpabilidade, surgindo a ideia de culpa presumida sob o prisma do dever genérico de não prejudicar (VENOSA, 2003, p.13), sustentando ser o sujeito responsável por riscos ou perigos que sua atuação promove, ainda que coloque toda a diligencia para evitar o dano.

Com a evolução da doutrina brasileira, embora tenha consagrado a responsabilidade subjetiva como princípio geral definidor da responsabilidade, positivado no artigo $186^{3} \mathrm{e} 927^{4}$ do Código Civil Brasileiro, com ela convive a responsabilidade objetiva para os casos especialmente previstos em lei.

Assim, o sistema brasileiro adota soluções ecléticas nos casos expressamente regulados, como é o caso da obrigação de indenizar a vítima de um acidente de trabalho, os consumidores e aqueles que foram lesados por prestadoras de serviços públicos.

Outra importante distinção que se faz é com relação à responsabilidade contratual e a extracontratual. Maria Helena Diniz (DINIZ, 2003, p.119) ensina que:

tem-se como responsabilidade contratual aquela oriunda de inexecução de negócio jurídico, ou seja, de falta de adimplemento ou de mora no

\footnotetext{
${ }^{3}$ Art.186. Aquele que, por ação ou omissão voluntária, negligência ou imprudência, violar direito e causar dano a outrem, ainda que exclusivamente moral, comete ato ilícito.

${ }^{4}$ Art. 927. Aquele que, por ato ilícito (arts. 186 e 187), causar dano a outrem, fica obrigado a reparálo.Parágrafo único. Haverá obrigação de reparar o dano, independentemente de culpa, nos casos especificados em lei, ou quando a atividade normalmente desenvolvida pelo autor do dano implicar, por sua natureza, risco para os direitos de outrem.
} 
cumprimento de qualquer obrigação contratual estabelecida pela vontade das partes.

Por sua vez, a responsabilidade extracontratual é resultante da violação de dever fundado num principio geral de direito, como o de respeito às pessoas e bens alheios; nesta responsabilidade o que se exige é um dever contido em uma norma legal, a qual violada pelo agente, causa dano à vitima (ALONSO, 2000, p.09).

A partir desta noção geral da responsabilidade civil e suas espécies, é possível adentrar ao tema da pesquisa e suas implicações, mas não sem antes abordar a temática da responsabilidade profissional.

\section{RESPONSABILIDADE PROFISSIONAL}

A responsabilidade profissional é um dos capítulos da responsabilidade civil em geral preponderantemente contratual.

Quem exerce certa profissão deve seguir parâmetros exigidos para o oficio e o desvio destes parâmetros, ao ocasionar danos, interessa ao dever de indenizar, pois se presume que qualquer pessoa que exerça uma profissão deve conhecer os meandros necessários para faze- lo ao contento.

Há dois tipos de obrigações que dividem os profissionais liberais e manuais, a obrigação de meio (STOCO, 2001, p.114), aquela quando a própria prestação nada mais exige do devedor do que, pura e simplesmente, o emprego de determinado maio sem olhar para o resultado, aplicada aos advogados, médicos, publicitários; como também há a obrigação de resultado (DINIZ, 2003, p.245), aquela em que o credor tem o direito de exigir do devedor a produção de um resultado sem o que se terá o inadimplemento da relação obrigacional, como por exemplo a contratação de um empreiteiro ou um cirurgião plástico.

Como dito, a responsabilidade profissional do advogado trata-se de uma obrigação de meio e não de resultado, estando nas exceções da regra geral do Código de Defesa do Consumidor que ao acolher a Teoria do Resultado e a responsabilidade objetiva dos prestadores de serviços, previu uma exceção elencada no artigo $14^{5}$, parágrafo quarto, reafirmando a responsabilidade pessoal do

\footnotetext{
${ }^{5}$ Art.14. $\S 4^{\circ} \mathrm{A}$ responsabilidade pessoal dos profissionais liberais será apurada mediante a verificação de culpa.
} 
profissional liberal, mediante a verificação de culpa, invocando a teoria subjetiva para poder fixar a responsabilidade do profissional.

\section{DA RESPONSABILIDADE CIVIL DO ADVOGADO}

O advogado, em seu ministério privado, presta serviço público, constituindo elemento indispensável à Administração da Justiça (DINIZ, 2003, p.250) e de grande importância para assegurar os direitos e garantias individuais dos cidadãos e dos grupos sociais.

Apesar de sua função participar, em nosso direito, de caráter de múnus público, ou seja, encargo, emprego ou função pública, o mandato judicial que é exigido pela legislação brasileira para o exercício profissional, apresenta, uma feição contratual, pois é inegável que as obrigações que surgem do exercício da advocacia são oriundas de uma convenção preexistente entre o advogado e seucliente.

Contudo, abre-se uma ressalva quando ao fato da responsabilidade do advogado ser contratual, nos casos em que atua como defensor público ou procurador de entidade pública (Estado, Município, Autarquias, advogado da União, etc).

Nestes últimos casos em que o instrumento de mandato não será exigido e responderá pelos danos causados a terceiros a pessoa jurídica de direito público em nome da qual o advogado atua, conforme as regras que disciplinam a responsabilidade do Estado (VIEIRA, 2003, p.87).

Quanto ao mandato, traz o Código Civil em seu artigo 653 a disposição de que "opera- se o mandato quando alguém recebe de outrem poderes para, em seu nome, praticar atos ou administrar interesses" e, ainda, em sua obra "Obrigações", traz o jurista Orlando Gomes (GOMES, 1994, p.34) o entendimento que o "mandato é o contrato pelo qual alguém se obriga a praticar atos judiciais ou administrar interesses por conta de outrapessoa".

Além da ideia de representação, encontra-se no mandato judicial a presença de outro negócio jurídico que é a prestação de serviço, inserido no mesmo contrato, tendo em vista o mandatário judicial não só apresentar seu constituinte, como também, prestar serviços profissionais no patrocínio de seus interesses.

Oriundas desse contrato firmado, o mandato faz surgir obrigações para 0 mandatário como o de agir em nome do mandando com cautela e atenção, 
repassando-Ihe as vantagens que obtiver em seu nome e, no final, prestar-Ihe contas dos atos praticados, pois, baseado no artigo $667^{6}$ do Código Civil e por força do entendimento dos tribunais pátrios, o mandatário responderá pelos prejuízos causados em decorrência do mau desempenho do mandato.

O contrato de prestação de serviços tem a natureza de obrigação de meio, que requer apenas prudência e diligência na prestação do serviço para atingir um resultado, sem, contudo, contar com ele. Assim, é o advogado que se compromete de dedicar-se com afinco à causa contratada, envidando esforços com a finalidade de alcançar a vitória desejada, sem, no entanto, se vincular efetivamente com o resultado.

Nesse entendimento, recorda a professora Maria Helena Diniz (DINIZ, 2003, p.251) que:

\begin{abstract}
pela procuração judicial, o advogado não se obriga necessariamente a ganhar a causa, por estar assumindo uma obrigação de meio e não de resultado. Logo, sua tarefa será a de dar conselhos profissionais e de representar seu constituinte em juízo, defendendo seus interesses pela melhor maneira possível. O advogado que tiver uma causa sob seu patrocínio deverá esforçar-se para que ela tenha bomtermo, de modo que não poderá ser responsabilizado se vier a perder a demanda, a não ser que o insucesso seja oriundo de culpa sua.
\end{abstract}

Verifica-se que se tais condutas forem observadas e a obrigação executada pelo advogado, não se Ihe poderá imputar nenhuma responsabilidade em eventual insucesso na causa, salvo se este for oriundo de culpa sua.

Com essa temática abordada, pode-se concluir que a responsabilidade do advogado é subjetiva e encontra justificativa na prova de sua culpa ou dolo, por ação ou omissão, lesivo a outrem, conforme prevê a regra geral da responsabilidade subjetiva prevista no ordenamento brasileiro nos artigos 927 caput e 186, ambos do Código Civil.

Portanto, para que se pretenda qualquer tipo de ressarcimento originário da conduta do advogado, como visto, é condição essencial a demonstração de sua conduta culposa, exatamente por se tratar de uma obrigação de meio e por haver expressa previsão legal, tanto no artigo 14 § 4º do Código de Defesa do Consumidor,

\footnotetext{
${ }^{6}$ Art. 667. O mandatário é obrigado a aplicar toda sua diligência habitual na execução do mandato, e a indenizar qualquer prejuízo causado por culpa sua ou daquele a quem substabelecer, sem autorização, poderes que devia exercer pessoalmente
} 
como no artigo $32^{7}$ do Estatuto da Advocacia e da Ordem dos Advogados do Brasil.

\subsection{Fundamentos Legais da Responsabilidade Civil do Advogado}

Os advogados são profissionais do direito, cujas atividades estão regulamentadas na Lei 8.906/94 que criou o denominado Estatuto da Advocacia e da Ordem dos Advogados do Brasil.

O Estatuto disciplina a atividade da advocacia no Brasil, firmando regras de grande repercussão na vida forense, trazendo mais dignidade à atividade profissional do advogado e mostrando sua indispensabilidade à Administração da Justiça e na luta pelo exercício pleno da cidadania do povo brasileiro.

O diploma legal em apreço estatui os direitos do advogado, os requisitos para sua regular inscrição na Ordem dos Advogados do Brasil, as incompatibilidades e os impedimentos que determinam a proibição, total ou parcial, do exercício da advocacia, a ética dos advogados, os fins e a organização da Ordem dos Advogados do Brasil,sua composição e estrutura, o processo disciplinar instaurado para apurar as faltas cometidas, dentre outras disposições.

As normas gerais de regência da responsabilidade civil do advogado, as quaisobrigam-no a reparar um dano causado a outrem, no exercício de sua profissão, estão espalhadas por todo Direito Positivo Brasileiro.

A primeira norma está disposta na Constituição Federal de 1988, artigo 133 que ressalta a indispensabilidade do papel do advogado na realização da Justiça, estabelecendo a inviolabilidade por seus atos e manifestações no exercício da profissão. Trata-se de norma de exoneração da responsabilidade, não podendo os danos, daí decorrentes, serem indenizados, salvo no caso de calúnia ou desacato. Essa peculiar imunidade é imprescindível ao exercício da profissão advocatícia que lida, especialmente, com as contradições e com os conflitos humanos, mas não deve, entretanto, ser confundida com a irresponsabilidade do profissional, mesmo porque, o inscrito na Ordem dos Advogados do Brasil que agir, com dolo ou culpa, deverá sofrer as consequências de seus atos, respondendo civil ou criminalmente, em qualquer outro caso, apurado em processo regular.

Outra norma reguladora está na Lei 8.078/90 - Código de Defesa do

\footnotetext{
${ }^{7}$ Art. 32. O advogado é responsável pelos atos que, no exercício profissional, praticar com dolo ou culpa.
} 
Consumidor, artigo $14, \S 4^{\circ}$ já mencionado, que abre importante exceção ao sistema de responsabilidade objetiva, na relação de consumo dos fornecedores de serviços, quando determina a verificação da culpa, no caso dos profissionais liberais.

Ainda há a Lei 8906/94 - Estatuto da Advocacia e da Ordem dos Advogados do Brasil, artigo 32 que estabelece a responsabilidade do advogado pelos atos, que no exercício da profissão, praticar com dolo ou culpa. Disso conclui-se que sem essas modalidades de fatos subjetivos da conduta, não se há de ver responsabilidade.

Os artigos 33 e 54, inciso V, também do Estatuto da Advocacia e da Ordem dos Advogados do Brasil, dispõem sobre o Código de Ética e Disciplina, aprovado e editado por seu Conselho Federal, e sobre a obrigatoriedade de seu cumprimento por todo profissional inscrito, devido ao fato de estarem elencados nesse Código alguns dos principais deveres do advogado, incluindo as condutas que devem ser mantidas com relação aos clientes, à comunidade ou outro profissional, o sigilo profissional, o dever de urbanidade, a contratação de honorários advocaticios, a publicidade de seus serviços, dentre outras disposições.

Outra norma reguladora está no Código Civil de 2002, artigo 927 caput que trata da responsabilidade civil, a ser analisada em conjunto com o artigo 186, também do Código Civil, que traz, em seu texto, de modo expresso, a definição de atoilícito.

Conclui-se que se exige do advogado habitual diligência e ética na condução dos negócios a ele confiados, uma vez que um deslize poderá resultar enormes prejuízos para os clientes. Cada vez mais, os profissionais do Direito devem guardar as cautelas ao desempenharem seu difícil múnus, pois a responsabilidade do advogado começa antes mesmo da efetivação do contrato, na fase pré-contratual, e continua surtindo efeitos além do término do contrato caracterizado pela fase póscontratual.

\subsection{Responsabilidade Pré-Contratual do Advogado}

A noção mais clara e viva que se tem é que o contrato é um processo que vai desde a fase pré-contratual, esta decomposta em fase das negociações e da oferta, passando à fase contratual distribuída em três fases menores: conclusão, eficácia e execução do contrato e indo até a fase pós-contratual, na qual ainda restam obrigações aos contratantes (VIEIRA, 2003, p.53). 
Com efeito, o contrato, a obrigação, não é uma coisa estática, mas sim dinâmica, no sentido de que se aperfeiçoam no decurso da relação travada.

A fase pré-contratual é caracterizada pelo encontro inicial do advogado com o cliente que the pede um conselho ou uma orientação sobre um problema que the aflige. Nessa fase, ainda, não se sabe ao certo se haverá demanda ou se irão celebrar um contrato para que o advogado defenda os interesses do cliente, pois desde as tratativas iniciais já surgem obrigações ao advogado.

Como pondera Caio Mário da Silva Pereira (PEREIRA, 2002, p.73) em sua obra Responsabilidade Civil:

Pode-se determinar a figura jurídica da responsabilidade pré-contratual quando uma pessoa entabula negociações com outra, induzindo-a a preparar-se para contratar e depois, injustificadamente, deixa de celebrar a avença.

É preciso alertar para o fato de que ninguém é obrigado a contratar. Tem a liberdade de fazê-lo ou não. Quando, porém, uma das partes procede de forma a convencer a outra da seriedade das tratativas, levando-a a adotar medidas tendentes à contratação, a efetuar despesas, assumir compromissos, etc, e de repente, retirase das negociações, causando dano à outra parte, responde pelo seu procedimento culposo.

Assim, o operador do Direito nessa fase deverá agir com lealdade, dar as informações necessárias, colaborar, evitar criar expectativas que sabe destinadas ao fracasso, não revelar informação e dados obtidos em decorrência desse encontro, guardando o sigilo necessário, preocupar-se com a outra parte e seus direitos, interromper a negociação quando se tenha certeza da inutilidade de seu prosseguimento (VIEIRA, 2003, p.54).

A responsabilidade pré-contratual será resultante de prejuízos causados nessa primeira fase negocial e, embora, resulte de ato ilícito, provém do descumprimento de dever específico imposto pela norma da boa-fé que estabelece os deveres de comportamento ético-jurídico para que os negócios jurídicos se realizem dentro dos valores como a correção, a lealdade e a confiança e, em face 
disso, obedece às regras da responsabilidade contratual.

\subsection{Responsabilidade Contratual do Advogado}

Após o contato inicial com o cliente, caracterizado pela fase pré-contratual, o advogado deverá realizar a prestação do serviço para o qual foicontratado.

O contrato firmado entre advogado e cliente é típico contrato de prestação de serviços (VIEIRA, 2003, p.55) que traz em seu bojo o contrato de mandato, cuja procuração é seu instrumento.

Nessa fase, deve o advogado, a todo tempo, proceder com a máxima lealdadee transparência, objetivando alcançar o resultado possível à defesa dos interesses de seu cliente. Ao cliente cabe entregar toda a documentação útil ao deslinde da demanda, prestaresclarecimentos necessários, apontar e identificar testemunhas do fato, relatar com precisão a mecânica do episódio, etc; enquanto caberá ao advogado reunir o material apresentado pelo cliente e elaborar a peça processual adequada e apresentá-la no prazo estabelecido em lei perante o órgão a que se destina e manter o cliente informado do andamento da demandapara que, assim, se realize a cooperação entre advogado e cliente.

\subsection{Responsabilidade Pós-Contratual do Advogado}

Terminadas e cumpridas as obrigações decorrentes do contrato, as partes não devem se considerar desobrigadas e libertas do vínculo que as uniu por, ainda, persistirem deveres que emergem da contratação (VIEIRA, 2003, p.63).

Em relação ao advogado, ele estará obrigado a cumprir vários deveres póscontratuais, baseado no princípio da boa-fé e no que dispõe o artigo $9^{\circ 10}$ do Código de Ética e Disciplina, como é o caso do dever do advogado de guardar os documentos do cliente, de manter sigilo sobre o que foi revelado no curso do processo, prestar contas, dentre outras.

\section{RESPONSABILIDADE DO ADVOGADO NO PLANEJAMENTO TRIBUTÁRIO}


Após a análise da responsabilidade civil e profissional do advogado, agora será possível analisar sua responsabilidade nos casos de planejamento tributário para clientes.

De plano, mister esclarecer que o planejamento tributário é um conjunto de sistemas legais que visam diminuir o pagamento de tributos. $O$ contribuinte tem 0 direito de estruturar o seu negócio da maneira que melhor lhe pareça, procurando a diminuição dos custos de seu empreendimento, inclusive dos tributos.

Também chamado de elisão fiscal, o planejamento tributário proporciona vantagens como evitar o pagamento de impostos indevidos, possibilitando a redução de custos ou adiar o pagamento de tributos, principalmente em casos em que a empresa não tem muito capital de giro disponível para investir, caso em que o planejamento tributário identifica oportunidades para retardar esse tipo de movimentação financeira e ter uma folga no fluxo de caixa.

Outra vantagem é o desenvolvimento do trabalho para manter a empresa legalizada, adotando os procedimentos corretos e atentos à legislação vigente, reunindo todas as informações necessárias sobre as obrigações do estabelecimento, de forma a evitar autuações.

É de notório conhecimento que o nível de tributação sobre as empresas e pessoas físicas no Brasil é absurdo, chegando a inviabilizar certos negócios. Também é sabido que os tributos representam importante parcela dos custos das empresas, senão a maior. Com a globalização da economia, tornou-se questão de sobrevivência empresarial a correta administração do ônus tributário.

Segundo o IBPT, no Brasil, em média, 33\% do faturamento empresarial é dirigido ao pagamento de tributos. Somente o ônus do Imposto de Renda e da Contribuição Social sobre o Lucro das empresas pode corresponder a $51,51 \%$ do lucro líquido apurado e da somatória dos custos e despesas, mais da metade do valor é representada pelos tributos (ZANLUCA, 2018, online). Assim, imprescindível a adoção de um sistema de economia legal, pois o planejamento fiscal acaba por ser um direito do contribuinte tão essencial quanto o é planejar o fluxo de caixa, fazer investimentos, estruturar as operações e logística, dentre outras.

Por óbvio que aqui se está a analisar o planejamento tributário legal, a elisão fiscal, tendo em vista ser indiscutível a responsabilidade do advogado quando comprovada práticas ilegais, ou seja, no uso de técnicas de evasão fiscal, como 
também nas condutas infratoras ao Código de Ética dos Advogados, quando surge a responsabilidade civil subjetiva de reparar os danos causados a terceiros.

No entanto, nos últimos anos, a ânsia arrecadatória da Receita Federal do Brasil tem estimulado a responsabilização de advogados e escritórios de advocacia na autuação depráticas lícitas de planejamento tributário.

Várias autuações do fisco vieram fundamentadas no fato de que os profissionais envolvidos seriam solidariamente responsáveis pelo tributo economizado por seus clientes em operações por eles assessoradas, alegando que ao participar da operação, seja assinando algum documento na qualidade de procurador, seja realizando a operação societária ou assessorando o planejamento tributário, o advogado passaria a apresentar um "interesse comum na situação que constitua o fato gerador da obrigação tributária", o que supostamente autorizaria a responsabilização com base no Código Tributário Nacional.

Em outras palavras, os autos de infração lavrados solidariamente contra advogados e escritórios, quando a Receita cobra tributos dos clientes, acaba por representar verdadeira coação ilegítima ao regular exercício da advocacia, como forma de inibir operações societárias e fiscais por meio de ameaça ao advogado de uma cobrança em valores extremamente altos.

\subsection{Posicionamento do Fisco para a atribuição da responsabilidade dos advogados no planejamento tributário}

Os fundamentos da recusa do direito de auto-organização são inúmeros, como abuso de direito, fraude à lei, simulação, abuso de formas, falta de propósito negocial e não raras vezes, a recusa vem acompanhada com a aplicação de multa qualificada de $150 \%$ e de representação fiscal para fins penais, uma forma encontrada pelo Fisco para intimidar o contribuinte no exercício da liberdade de planejar.

Nos últimos anos, objetivando inibir a adoção de gestões de tributos, as autuações fiscais pretendem atribuir a advogados e consultores responsabilidade solidária pelo cumprimento das obrigações tributárias dos contribuintes, com fundamento no artigo 124, I do Código Tributário Nacional, segundo o qual: "são solidariamente obrigadas: I - as pessoas que tenham interesse comum na situação que constitua o fato gerador da obrigação principal". 
Referidas autuações têm se valido de uma interpretação ampla do conceito de interesse comum para incluir no rol de responsáveis solidários pessoas que, mesmo não estando no mesmo polo da relação obrigacional, tenham auferido algum proveito com a falta de recolhimento do tributo.

O dispositivo mencionado do CTN diz que o requisito mais importante para a configuração da solidariedade é o interesse comum, contudo, a Receita Federal ${ }^{8}$, em Parecer Normativo 04, 10 de dezembro de 2018, amplamente divulgado, unilateralmente, amplia o conceito de interesse comum para interesse econômico ou negocial.

Apesar da maior parte da doutrina considerar a medida inconstitucional e ilegal, tendo por base o entendimento pacificado do Superior Tribunal de Justiça ${ }^{9}$ no sentido de que a aplicação do artigo 124, inciso I, do CTN só pode ocorrer quando o interesse comum na realização do fato gerador seja o interesse jurídico, que pressupõe a prática conjunta do fato, a Receita Federal continua a exarar autuações aos profissionais advogados e consultores tributários.

O argumento adotado pelo Fisco nas autuações é de que a responsabilidade tributária solidária decorre de interesse comum da pessoa responsabilizada na situação vinculada ao fato jurídico tributário, que pode ser tanto o ato lícito que gerou a obrigação tributária como o ilícito que a desfigurou.

Fato relevante considerado pelo Fisco é a forma de pagamento dos honorários dos advogados. Se os valores forem pagos por hora de trabalho, não há problema com o Fisco, mas se forem acordados honorários com base em porcentagem dos ganhos obtidos com o planejamento tributário, há risco de o profissional ser responsabilizado solidariamente, considerando materializado seu interesse na relação tributária.

Segundo o parecer da Receita acima mencionado, são ilícitos que podem resultar na responsabilização: a) abuso da personalidade jurídica em que se desrespeita a autonomia patrimonial e operacional das pessoas jurídicas mediante direção única ("grupo econômico irregular"); b) evasão, simulação e demais atos

\footnotetext{
8 PARECER NORMATIVO COSIT/RFB № 04, DE 10 DE DEZEMBRO DE 2018. NORMAS GERAIS DE DIREITO TRIBUTÁRIO. RESPONSABILIDADE TRIBUTÁRIA. SOLIDARIEDADE. ART. 124, I, CTN. INTERESSE COMUM. ATO VINCULADO AO FATO JURÍDICO TRIBUTÁRIO. ATO ILÍCITO. GRUPO ECONÔMICO IRREGULAR. EVASÃO E SIMULAÇÃO FISCAL. ATOS QUE CONFIGURAM CRIMES. PLANEJAMENTO TRIBUTÁRIO ABUSIVO. NÃO OPOSIÇÃO AO FISCO DE PERSONALIDADE JURÍDICA APENAS FORMAL. POSSIBILIDADE.

${ }^{9}$ Recursos Especiais 859.616, 834.044 e 884.845.
} 
deles decorrentes e c) abuso de personalidade jurídica pela sua utilização para operações realizadas com o intuito de acarretar a supressão ou a redução de tributos mediante manipulação artificial do fato gerador (planejamento tributário abusivo).

Entretanto, para configuração da responsabilização, deve-se comprovar que a pessoa a ser responsabilizada tenha vínculo com o ato e com a pessoa do contribuinte ou do responsável por substituição, demonstrando-se o vínculo com o fato jurídico tributário (incluídos os atos ilícitos a ele vinculados) e para fazer tal demonstração é que surgem inúmeras teses fiscais para os mais variados casos, muitas delas meras presunções de ilícitos.

O alto risco da conduta adotada pela Receita Fiscal é quanta à responsabilidade criminal de tributaristas, quando, não raras vezes, o profissional é representado criminalmente por teses fiscais sobre planejamentos tributários, uma nítida forma de caracterizar o avanço do poder estatal na tentativa de responsabilizar advogados por serviços prestados a clientes.

\subsection{Precedentes sobre a não responsabilização dos advogados em planejamentos tributários}

Apesar do entendimento extensivo da Receita Federal quanto ao termo 'interesse comum”, a doutrina é bastante estrita na sua interpretação.

Como pode se demonstrar na lição de Paulo de Barros Carvalho (CARVALHO, 1996, p.220), o mero interesse comum no fato não é suficiente para a atribuição da solidariedade:

O interesse comum dos participantes no acontecimento factual não representa um dado satisfatório para a definição do vínculo da solidariedade. Em nenhuma dessas circunstâncias cogitou o legislador desse elo que aproxima os participantes do fato, o que ratifica a precariedade do método preconizado pelo inc. I do art. 124 do Código.

Vale sim, para situações em que não haja bilateralidade no seio do fato tributado como, por exemplo, na incidência do IPTU, em que duas ou mais pessoas são proprietárias do mesmo imóvel. Tratando-se, porém, de ocorrências em que o fato se consubstancie pela presença de pessoas em posições contrapostas, com objetivos antagônicos, a solidariedade vai instalar-se entre sujeitos que estiveram no mesmo pólo da relação, se e 
somente se for esse o lado escolhido pela lei para receber o impacto jurídico da exação. É o que se dá no imposto de transmissão de imóveis, quando dois ou mais são os compradores; no ICMS, sempre que dois ou mais forem os comerciantes vendedores; no ISS, toda vez que dois ou mais sujeitos prestarem um único serviço ao mesmo tomador.

O balizamento da extensão do que se deve entender por interesse comum nos termos do artigo 124, I do CTN foi precisamente anotado pela conselheira Bianca Rothschild, do Conselho Administrativo de Recursos Fiscais (Carf), em voto proferido no Processo 15983.720065/2015-11 (Acórdão 2402-005.703), "caso Neymar", in verbis:

O dispositivo acima pugna pela solidariedade quando há interesse comum na constituição do fato gerador da obrigação principal. Ou seja, não basta que haja interesse financeiro nos resultados advindos da situação, mas um envolvimento direto na materialização do fato econômico tributável. Em outras palavras, há que se reconhecer que tal interesse comum é um interesse jurídico e não um interesse meramente econômico.

Neste mesmo voto, diferenciando o interesse jurídico do interesse meramente econômico, a conselheira prossegue:

O responsável obrigado solidário - para utilizar a redação do Código Tributário Nacional - portanto, é a pessoa que esteja relacionada intrinsecamente, em comum com outra, na realização do núcleo do aspecto material da respectiva hipótese de incidência tributária. Desta forma, resta-se configurado o interesse jurídico de tal solidário.Ou seja não basta nem a mera participação na situação fática que gera o fato gerador e nem o benefício econômico para se caracterizar o interesse comum. Prossegue, neste sentido o Professor Luís Eduardo Schoueri:Mesmo que duas partes em um contrato fruam vantagens por conta do não recolhimento de um tributo, isso não será, por si, suficiente para que se aponte um 'interesse comum' em lesar o Fisco. Pode o comprador, até mesmo, ser conivente com o fato de o vendedor não ter recolhido o imposto que devia. Pode, ainda, ter tido um ganho financeiro por isso, já que a inadimplência do vendedor poderá ter sido refletida no preço. Ainda assim, comprador e vendedor não têm 'interesse comum' no fato jurídico tributário. 
Quanto aresponsabilização solidária do advogado ou escritório de advocacia, com fundamento no artigo 124, I do CTN, a questão foi examinada pelo Acórdão 2301-004.800, da 1ํㅡㄹ Turma Ordinária da 3ª Câmara da 2ª Seção do Carf, de 17 de agosto de 2016, que versou sobre exigências de contribuições previdenciárias ao município de Elias Fausto em razão de compensações indevidas. A ementa ${ }^{10}$, na parte relativa à responsabilidade solidária imputada a advogados, dispõe sobre a necessidade da presença do interesse jurídico comum, não se aplicando ao caso a solidariedade quanto ao mero interesse econômico entre os sujeitos da relação jurídica.

Já a questão de responsabilização solidária de empresa de consultoria tributária, com fundamento no mesmo dispositivo do CTN, foi tratada no Acórdão 2402-005.697 ${ }^{11}$, da 2 ${ }^{\underline{a}}$ Turma Ordinária da 4⿳a Câmara da 2ª Seção do Carf, de 14 de março de 2017, reafirmando o entendimento do Superior Tribunal de Justiça, no qual tem-se que o interesse comum na situação que constitua o fato gerador da obrigação principal implica que as pessoas solidariamente obrigadas sejam sujeitos da relação jurídica que deu azo à ocorrência do fato imponível.

Por sua vez, no acórdão do Resp 884.845-SC, de relatoria do Ministro Luiz Fux, há requisitos descritos em lei para a responsabilidade solidária quanto a identificação do 'interesse comum', o qual deverá, obrigatoriamente, ser interpretado de forma sistemática, sob pena de se ferir a lógica jurídico-tributária, caso haja a integração, no pólo passivo da relação jurídica, de alguém que não tenha tido

\footnotetext{
${ }^{10}$ RESPONSABILIDADE PASSIVA TRIBUTÁRIA. SOLIDARIEDADE. ESCRITÓRIO DE ADVOCACIA. INTERESSE COMUM.A aplicação da responsabilidade passiva solidária, contida no art. 124, I, do CTN, exige a presença de interesse jurídico comum, ou seja, que as pessoas sejam sujeitos da relação jurídica que deu azo à ocorrência do fato gerador. O mero interesse econômico entre tais sujeitos ou mesmo o interesse jurídico reflexo, oriundo de outra relação jurídica afasta a aplicação do mencionado dispositivo legal.

${ }^{11}$ SUJEIÇÃO PASSIVA SOLIDÁRIA. EMPRESAS DE ASSESSORIA. INEXISTÊNCIA.O fato de as empresas de assessoria serem executoras do planejamento não significa que elas tenham interesse comum na situação que constitua o fato gerador da obrigação principal, muito menos que a obrigação decorra de atos praticados com excesso de poderes ou infração de lei, contrato social ou estatutos. A firme linha de orientação adotada pelos julgados do Carf em defesa da impossibilidade de aplicação do artigo 124, I do CTN a advogados e consultores foi haurir seus fundamentos na já tradicional jurisprudência do Superior Tribunal de Justiça, que tem seguido com rigor a orientação doutrinária acima exposta. Paradigmáticos desse entendimento são os acórdãos da 1 a Turma do STJ proferidos nos REsp 834.044-RS (rel. min. Denise Arruda) e 884.845-SC (rel. min. Luiz Fux), que examinaram a validade da responsabilização solidária de empresas do mesmo grupo econômico com fundamento em "interesse comum.
} 
qualquer participação na ocorrência do fato gerador da obrigação, ou seja, na realização do fato imponível tributário. ${ }^{12}$

Em outra decisão ${ }^{13}$ proferida pelo CARF, o entendimento da não responsabilização de advogados continua sendo mantida, como é o caso da decisão proferida pela $2^{\underline{a}}$ Turma da $4^{a}$ Câmara da $2^{\underline{a}}$ Seção onde foi excluída a autuação fiscal uma consultoria e uma empresa de investimentos que assessoraram cliente em um planejamento tributário, fazendo constar no julgado que o fato de as empresas de assessoria serem executoras do planejamento não significa que elas tenham interesse comum na situação que constitua fato gerador da obrigação principal, muito menos que a obrigação decorra de atos praticados com excesso de poderes ou infração de lei, contrato social ou estatutos.

De fato, as decisões do Carf confirmam, no âmbito administrativo, a jurisprudência do Superior Tribunal de Justiça (STJ), que de acordo com os ministros, têm-se entendido que há um interesse econômico e não jurídico por parte das consultorias e por isso não poderiam ser responsabilizadas por não preencherem os requisitos do inciso I do artigo 124 do Código Tributário Nacional (CTN), muito embora da insistência do Fisco em afirmar que os profissionais envolvidos seriam solidariamente responsáveis pelo tributo economizado por seus clientes em operações por eles assessoradas.

Não se discute aqui a possibilidade de se responsabilizar um advogado ou consultor que propôs, sob a aparência de planejamento tributário lícito, esquemas de evasão ilícita de tributos. Nesse caso, porém, a solução juridicamente admissível

\footnotetext{
12PROCESSUAL CIVIL. TRIBUTÁRIO. RECURSO ESPECIAL. ISS. EXECUÇÃO FISCAL. LEGITIMIDADE PASSIVA. EMPRESAS DO MESMO GRUPO ECONÔMICO. SOLIDARIEDADE. INEXISTÊNCIA. VIOLAÇÃO DO ART. 535 DO CPC. INOCORRÊNCIA.1. A solidariedade passiva ocorre quando, numa relação jurídico-tributária composta de duas ou mais pessoas caracterizadas como contribuintes, cada uma delas está obrigada pelo pagamento integral da dívida. Ad exemplum, no caso de duas ou mais pessoas serem proprietárias de um mesmo imóvel urbano, haveria uma pluralidade de contribuintes solidários quanto ao adimplemento do IPTU, uma vez que a situação de fato - a copropriedade - é-Ihes comum...6. Deveras, o instituto da solidariedade vem previsto no art. 124 do CTN, verbis:Art. 124. São solidariamente obrigadas:I - as pessoas que tenham interesse comum na situação que constitua o fato gerador da obrigação principal;II - as pessoas expressamente designadas por lei.7. Conquanto a expressão "interesse comum" - encarte um conceito indeterminado, é mister proceder-se a uma interpretação sistemática das normas tributárias, de modo a alcançar a ratioessendi do referido dispositivo legal. Nesse diapasão, tem-se que o interesse comum na situação que constitua o fato gerador da obrigação principal implica que as pessoas solidariamente obrigadas sejam sujeitos da relação jurídica que deu azo à ocorrência do fato imponível. Isto porque feriria a lógica jurídico-tributária a integração, no pólo passivo da relação jurídica, de alguém que não tenha tido qualquer participação na ocorrência do fato gerador da obrigação (....).

${ }^{13}$ Processo no $11065.721067 / 2013-76$, 2ª Turma, 4ª Câmara, 2ª Seção, CARF.
} 
não é a exigência do tributo a título de responsabilidade solidária, com fundamento em "interesse comum", mas, sim, a responsabilização do profissional na esfera cível (ESTRADA, 2017, online).

O grande risco que vivem hoje os profissionais não está, evidentemente, nas operaçõesfraudulentas, pois aqueles que as praticam devem ser rigorosamente punidos, inclusive e, especialmente, pelos tribunais éticos que supervisionam o regular exercício da profissão (ESTRADA, 2017, online).

A problemática toda gira em torno das cada vez mais frequentes desconsiderações unilaterais de operações pelo Fisco sob a acusação de planejamento abusivo, entretanto, até então, o limite da autuação profissional sempre esteve amparado nos termos da lei, vinculado do princípio da legalidade. Atualmente, o limite e a definição do que seja abusivo ou não passou a ser de livre apreciação dos órgãos de fiscalização, cujos interesses arrecadatórios acabam por se sobressair.

O que se verifica como esta nova forma de interpretação fiscal é a ameaça ao livre exercício profissional, lesando aos direitos dos contribuintes em planejar licitamente seus negócios, sob o objetivo velado de proibir o planejamento tributário para aumentar a arrecadação.

\section{CONCLUSÃO}

A responsabilidade civil é hoje um dos temas jurídicos mais discutidos, ensejando diversas reflexões. É nesse cenário que avulta a responsabilidade civil do advogado.

É indubitável que se exige, cada vez mais, dos advogados uma postura ética, condizente com as premissas contidas na Lei 8.906, de 04.07.94 (Estatuto da Advocacia e da $\mathrm{OAB}$ ), no Código de Ética e Disciplina da OAB, como também nas várias outras normativas legais que determinam que aqueles profissionais que não trilharem esse caminho, poderão ser responsabilizados civilmente pelos danos que acarretarem aos seus clientes.

Após o estudo dos elementos que caracterizam a responsabilidade civil do advogado, bem como a identificação de algumas das principais situações em que este profissional poderá ser responsabilizado, o que se extrai das presentes considerações é que a responsabilidade civil do advogado está intrinsecamente 
relacionada à liberdade com que desempenha seu ofício.

Além disso, há elevação da atividade advocatícia ao plano constitucional, declarando o advogado como indispensável à administração da Justiça, por causa do caráter eminentemente público do seu encargo, que objetiva garantir sustentação democrática ao país e, principalmente, efetivar o acesso à Justiça, por ser ele o defensor dos interesses da sociedade junto aos órgãos jurisdicionais.

Diante desta função social exercida pelo advogado é que gerou a inquietação de se apurar sua responsabilidade nos casos de planejamento tributário, considerando o esforço ilegal do Fisco em Ihe atribuir a responsabilidade solidária no recolhimento de tributos que foram deixados de recolher diante da aplicação de técnicas legais de gestão de tributos.

Não se fala aqui sobre técnicas ilegais, práticas de evasão fiscal, cuja conduta de fato deverá ser reprimida e punibilizada.

No entanto, quando se fala de elisão fiscal, mais que a responsabilidade solidária tributária, surge a preocupação pelo fato do Fisco estar colocando os profissionais tributaristas nos bancos dos réus quando fazem representações penais pelas práticas de assessoria fiscal.

De fato, o que se verifica é a afronta do texto de lei e da jurisprudência dos Conselhos Administrativos Fiscais e do próprio Superior Tribunal de Justiça, os quais são contundentes em afirmar que inexiste responsabilidade do advogado nos casos de planejamento tributário, gestão de tributos lícita, porquanto inexiste interesse comum na situação que constitua o fato gerador da obrigação principal, afastando a obrigatória caracterização do interesse jurídico, uma vez que o interesse econômico não é fato relevante para eventual responsabilização.

Para a comunidade jurídica, fica claro o intuito ameaçador do Fisco em tentar restringir e inibir o uso do planejamento tributário por meio do ataque direto e abusivo a advogados tributaristas, com claro objetivo de fomentar a arrecadação de tributos.

Dentro desse quadro, impõe-se, mais do que nunca, ter plena ciência dos riscoscontidos no exercício da profissão para poder melhor evitá-los, direcionando os profissionais advogados às condutas éticas, primando pela dignidade, lealdade e honestidade fundamentais para o bom desempenho de suas funções, assegurando, assim, a credibilidade de toda a categoria profissional. 


\section{REFERÊNCIAS BIBLIOGRÁFICAS}

ALONSO, Paulo Sérgio Gomes. Pressupostos da Responsabilidade Civil Objetiva. São Paulo: Saraiva, 2000.

BARBOSA, Kelly de Sousa. FERREIRA, Leticia de Oliveira Catani. A Essencialidade do Advogado na Administração da Justiça Brasileira. Brasília: XXVI Encontro Nacional do Conpedi:

2017.Disponível

em https://www.conpedi.org.br/publicacoes/roj0xn13/f1iv6jxw/mFMpSXz7brJyqK67.pd f. Acesso em 11 de fevereiro de 2020.

CALCINI, Fábio Pallaritti; CRUZ, Juliana Campos de Carvalho. RESPONSABILIDADE TRIBUTÁRIA SOB O ENFOQE DA SÚMULA 435 DO STJ. Revista Juridica, [S.I.], v. 3, n. 56, p. 326 - 353, jul. 2019. ISSN 2316-753X. Disponível em: <http://revista.unicuritiba.edu.br/index.php/RevJur/article/view/3580/371371971>. Acesso em: 17 abr. 2020. doi:http://dx.doi.org/10.21902/revistajur.2316753X.v3i56.3580.

CARVALHO, Paulo de Barros. Curso de Direito Tributário, São Paulo: Saraiva,1996.

CORREA, Orlando de Assis. Comentários ao Estatuto da Advocacia e da Ordem dos Advogados do Brasil. Rio de Janeiro: Aide, 1997.

DIAS, José de Aguiar. Da responsabilidade civil. Rio de Janeiro: Forense: 1960.

DINIZ, Maria Helena. Curso de Direito Civil Brasileiro. Responsabilidade Civil. São Paulo: Saraiva, 2003.

ESTRADA, Roberto Duque. Carf afirma inexistir responsabilidade solidária de advogados. Disponível em https://www.conjur.com.br/2017-jun-07/consultortributario-carf-afirma-inexistir-responsabilidade-solidaria-advogados. Acesso em 12 de fevereiro de 2020.

GOMES, Orlando. Obrigações. São Paulo: Forense, 1994.

GRUBER, Rosicléia. Manual Estatutário e Ético do Advogado. Curitiba: Juruá, 2010.

LUCCA, Newton de. Da ética Geral à Ética Empresarial. São Paulo: Quartier Latin do Brasil, 2009.

PEREIRA, Caio Mario da Silva. Responsabilidade Civil. Rio de Janeiro: Forense, 2002.

STOCO, Rui. Tratado de Responsabilidade Civil. São Paulo: RT, 2001. 
VENOSA, Silvio de Salvo. Direito Civil. Responsabilidade Civil. Vol.4. São Paulo: Atlas, 2003.

VIEIRA, Antônio Laert Jr. Responsabilidade Civil do Advogado. Rio de Janeiro: Lúmen, 2003.

ZANLUCA, Júlio César. Planejamento Tributário. São Paulo, 2018. Disponível em http://www.portaltributario.com.br/planejamento.htm. Acesso em 11 de fevereiro de 2020. 